\title{
Influence of forest type and host plant genetic relatedness on the canopy arthropod community structure of Quercus crassifolia
}

\author{
Efraín Tovar-Sánchez ${ }^{1 *}$, Erwin Martí-Flores ${ }^{1}$, Leticia Valencia-Cuevas ${ }^{1}$ and Patricia Mussali-Galante ${ }^{2}$
}

\begin{abstract}
Background: Quercus crassifolia is an oak species with characteristics of foundation species, which is a canopy dominant element of different forest types that supports a wide diversity of associated species. Therefore, it is an excellent system to address important ecological questions. We analyzed the effect of individual genetic relatedness of the host plant, forest type (Abies-Quercus, Quercus-Pinus, and Quercus forest), and season (dry vs. rainy) on the canopy arthropod community structure. Thirty oak canopies were fogged (five individuals/season/forest type).

Results: We identified 442 arthropod species belonging to 22 orders. The highest values of density, diversity, and richness were recorded during the rainy season for each forest type. Also, the non-metric multidimensional scaling (NMDS) analysis showed a separation of the host tree species for each forest type. During the rainy season, the highest values of density, diversity, and richness in each forest type were recorded. A separation of host tree was found for each forest type. In general, diversity and richness of canopy arthropods showed the following pattern: Abies-Quercus > Quercus-Pinus > Quercus, while density showed an inverse pattern. An increase of the diversity of canopy arthropods is significantly related to an increase of host plant genetic diversity, independently of the type of forest and of the season.
\end{abstract}

Conclusions: In terms of conservation, if arthropod species respond to genetic differences among host plants, it becomes important to conserve genetic diversity of foundation species, since it is fundamental to preserve diversity of their associated arthropod communities.

Keywords: Quercus; Foundation species; Individual genetic diversity; Microsatellites; Forest type; Arthropods community

\section{Background}

Efforts toward conservation strategies have focused on the preservation of charismatic animals like mammals, birds, and other terrestrial vertebrates. Most of these species have been described, their ecologies known, or threats to their habitats often documented. This information has been used to implement management and conservation programs (Leather et al. 2008). In contrast, efforts toward arthropod conservation have been limited because most of the species have not been described or their life history and roles that they play within communities are unknown (Stork 1998). Despite this, it has been

\footnotetext{
* Correspondence: efrain_tovar@uaem.mx

'Departamento de Sistemática y Evolución, Centro de Investigación en Biodiversidad y Conservación, Universidad Autónoma del Estado de Morelos, Av. Universidad 1001, Col. Chamilpa, Morelos, Cuernavaca CP 62209, Mexico Full list of author information is available at the end of the article
}

documented that this phylum contains the highest species diversity on earth (from 2.5 to 3.7 million of species Hamilton et al. 2010); additionally, insects play important ecological roles and are involved in processes that maintain forest ecosystems.

Therefore, efforts to conserve biological diversity should include the protection of the arthropod fauna. Fortunately, in recent years, several hypotheses have been proposed about the conservation of biodiversity, including habitat conservation, diversity hotspots, biogeographic crossroads, and the conservation of ecosystem processes (Bangert et al. 2005). Coupled with this perspective of integrating conservation, unification and simplification of the principles that govern communities can be of great value to improve the ability to generate conservation strategies (Wimp et al. 2004).

\section{实 Springer}


Natural communities have been considered complex ecological systems, where its structure and functioning are determined by the interaction of different factors, whose effects are spatially and temporally variable (Bailey and Whitham 2007). One such factor is the heterogeneity of forests, for example, the forest canopy can be structurally more complex when it consists of more than one tree species (Sobek et al. 2009). This suggests that tree species communities with high levels of species richness will increase the habitat heterogeneity, resulting in more resources and conditions. In this sense, there are studies that have reported a positive relationship between plant diversity and arthropod species richness (Sobek et al. 2009).

Oak canopies represent an ideal system to study their associated communities, since they can be physically delimited. It has been documented that canopies support a great diversity of organisms (Nadkarni et al. 2004). In particular, arthropods are considered the main component of the canopy-associated communities in terms of abundance and species diversity (Stork and Hammond 1997). To study canopy arthropod communities, it is important to conduct studies at local scales. This approach minimizes the effects of other factors (e.g., geological history, topography, climate, forest age, altitude, and disturbance) that may also modify community structure parameters.

In the last 20 years, various studies have documented that genetic variation of foundation species ('species that structure a community by creating locally stable conditions for other species and by modulating and stabilizing fundamental ecosystem processes', Dayton 1972) can have an extended effect beyond the individual leading to interactions with other species to produce community and ecosystem phenotypes (Whitham et al. 2006). For example, studies with eucalyptus (Dungey et al. 2000), willows (Hochwender and Fritz 2004), cottonwoods (Wimp et al. 2004), and oaks (Tovar-Sánchez and Oyama 2006a, b) have demonstrated that plant genetics can influence the associations and interactions of communities associated with these species.

To evaluate the genetic relatedness effects of the host plant on the arthropod community structure, the majority of studies have been done at an intra-specific level (among populations or patches of mixed genotypes vs. monocultures; Hochwender and Fritz 2004), in hybrid complexes (among different genetic classes: parentals, F1 hybrids, and backcross hybrids; Wimp et al. 2004; TovarSánchez and Oyama 2006a, b), and few studies have been conducted at the intra-individual level (Tovar-Sánchez et al. 2013). Therefore, studies that address the influence of intra-individual genetic variability on canopy arthropod community are valuable because they explore other factors that may play a significant role in community assemblage. Moreover, most of the studies have been conducted under experimental conditions (Hochwender and Fritz 2004) rather than on natural systems (Ferrier et al. 2012).

These effects have been assessed in terms of species richness, similarity, and diversity. For example, Wimp et al. (2004), Tovar-Sánchez and Oyama (2006b), and Ferrier et al. (2012) found that greater genetic diversity of the host plant favors richness and diversity of the associated communities, because more genetically diverse host plants offer a wider range of resources and conditions. Likewise, Bangert et al. (2005) found that genetically similar host plant species will hold more similar communities, due to a major similarity in physical, chemical, and phenological characteristics. In terms of conservation, if arthropod species respond to genetic differences among host plants, it becomes important to conserve genetic diversity of foundation species, since it is fundamental to preserve diversity of their associated arthropod communities (Bangert et al. 2005; Tack and Roslin 2011).

Mexico contains 161 species of oaks (Quercus, Fagaceae) from which $68 \%$ of these appear to be endemic (Valencia 2004). In consequence, Mexico is considered one of the centers of diversification of the genus (Valencia 2004). In general, oaks represent an ideal system to study the effects of host plant genetic relatedness on their associated canopy communities, because they are dominant elements of temperate forest canopies and their genetic diversity levels are high (Dutech et al. 2005). Likewise, it has been documented that oaks are involved in important ecosystem processes as nutrient recycling and water balance (Madritch and Hunter 2002). This information invites us to think that most oak species can be considered as foundation species.

Mexican temperate forests are threatened by deforestation activities $(\approx 314,000$ ha/year, FAO 2006), resulting in a significant loss of habitat. When the foundation species are the habitat, a loss of genetic diversity will result in a loss of habitat that could have a potential effect on species across multiple trophic levels and major taxonomic groups (Bangert et al. 2005). The consideration of genetic diversity conservation can be a general and efficient approach to conserving processes (evolutionary and ecological) and diverse assemblages of plants and animals.

Quercus crassifolia is an excellent system to study the mechanisms that regulate its associated arthropod communities, due to its wide geographical distribution and its association with different types of forests, and it is a dominant canopy element in temperate forests which supports a wide diversity of flora and fauna.

As a consequence, and because there are no studies that analyze simultaneously the influence of genetic relatedness of foundation species and forest type on their associated arthropod fauna, the goal of this study was to evaluate the effect of individual genetic relatedness of Q. crassifolia on the canopy arthropod community structure in terms of 
composition, species richness, diversity, and density. Also, we determined if the arboreal community structure changes between forest types. We predict that the host plant with the highest levels of intra-individual genetic diversity and the highest level of surrounding arboreal species richness should support more diverse arthropod communities, because they offer a wider array of resources and conditions to be exploited.

\section{Methods}

\section{Study site}

The study areas are situated at the Parque Nacional El Chico (PNECh), which was decreed as a protected natural area in 1898. It possesses a surface of 2,739 ha and is located at the Austral portion of Transmexican Volcanic Belt (TVB) $\left(20^{\circ} 10^{\prime} \mathrm{N}, 98^{\circ} 41^{\prime} \mathrm{W}\right.$, CONANP 2006). The altitude oscillates between 2,600 to 3,050 m. Mean annual temperature oscillates between $12^{\circ} \mathrm{C}$ and $18^{\circ} \mathrm{C}$, and more than $90 \%$ of the annual precipitation of $1,479.5 \mathrm{~mm}$ falls from April to October (CONANP 2006).

Inside the PNECh, the principal forest types are Abies, Quercus, Abies-Quercus, Pinus, Quercus-Pinus, Juniperus forest and grassland (CONANP 2006). Because it has been documented that canopy arthropod community structure varies spatially (Tovar-Sánchez et al. 2003), we chose three forest types (Quercus, Quercus-Pinus, and Abies-Quercus) within the PNECh to minimize historic and environmental site effects. We presume that because these three forest types are located within the same geographic area, with similar geological and evolutive events, the influence of these factors should be reduced when assessing their associated arthropod communities. Therefore, these sites have the same geological history, weather (temperate subhumid), altitude (between 2,550 and $2,750 \mathrm{~m}$ ), forest age (mature forest), tree height (between 10 and $13 \mathrm{~m}$ ), soil type (volcanic origin), and degree of disturbance (no local disturbance inside the forest). In addition, in the three forest types, Q. crassifolia is a canopy representative element.

Quercus forest is located at an altitude of 2,750 m, and various arboreal species are found in this type of forest: Quercus alpenses, Q. crassifolia, Quercus glabrescens, Quercus greggii, Quercus laurina, Quercus mexicana, and Arbutus glandulosa.

Quercus-Pinus forest is situated at an altitude of 2,550 m, and it is shaped by the following arboreal species: Q. affinis, Q. crassifolia, Q. glabrescens, Q. greggii, Q. laurina, Pinus rudis, Pinus teocote, Abies religiosa, A. glandulosa, Arbutus xalapensis, and Ilex tolucana.

Abies-Quercus forest is located at an altitude of 2,720 $\mathrm{m}$, where the following arboreal species are found: A. religiosa, $Q$. affinis, Q. crassifolia, Q. glabrescens, $Q$. greggii, Quercus potosina, Quecus rugosa, Alnus arguta, A. xalapensis, A. glandulosa, Buddleia cordata, Cercocarpus macrophyllus, Cornus disciflora, Garrya laurifolia, I. tolucana, and Vibornum elatum.

Hence, a gradient of arboreal species among forest types is observed: Abies-Quercus $(n=16)>$ Quercus-Pinus ( $n=$ $11)>$ Quercus $(n=7)$.

The Quercus forest is located at 6.3 linear $\mathrm{km}$ from the Quercus-Pinus and Abies-Quercus forests. The QuercusPinus and Abies-Quercus forests are separated by a distance of 3.5 linear $\mathrm{km}$.

\section{Study species}

Q. crassifolia Humboldt and Bonpland is a red oak (section Lobatae) that includes large trees up to $23 \mathrm{~m}$ in height with a trunk diameter of $1 \mathrm{~m}$ and deciduous leaves. $Q$. crassifolia can differ easily from other red oaks by its leaf characteristics such as ovate, obovate, or elliptic shape with a coriaceus upper surface, the lower surface is yellow tomentose, orange or brown, presenting from one to ten teeth (Romero et al. 2002) and not glandular sessile fasciculate and the solitary unicellular trichomes. This species presents a broad geographical distribution in Mexico, occupying the major mountain ranges at an altitude of 2,500 to 2,800 m (Romero et al. 2002).

\section{Canopy arthropod community}

Canopy arthropod community structure of $Q$. crassifolia at the PNECh was determined by sampling ten trees in each forest type, five trees during dry season (February 2005) and five trees during rainy season (August 2005). Sampling was done seasonally, which allowed having a representative annual sample of the canopy arthropod fauna, as suggested by previous studies, which have demonstrated that seasonality modifies both composition and richness of the canopy arthropod fauna (Tovar-Sánchez et al. 2003; Tovar-Sánchez and Oyama 2006a; Tovar-Sánchez 2009). We selected individual oaks of 10 to $13 \mathrm{~m}$ (mean $\pm \mathrm{SE}$, $11.42 \pm 0.17 \mathrm{~m}$ ) in height and between 20.21 and $32.64 \mathrm{~m}^{2}$ (mean $24.89 \pm 3.27 \mathrm{~m}^{2}$ ) of crown cover. Crowns that do not overlap with any other tree within the oak forest were sampled. Arthropods were collected by fogging with $750 \mathrm{ml}$ of non-persistent insecticide (AquaPy, AgrEvo, Mexico City) the entire canopy of a single tree. AquaPy is composed by $30 \mathrm{~g} / \mathrm{l}$ of natural pyrethrine, synergized with $150 \mathrm{~g} / \mathrm{l}$ of piperonyl-but-oxide. Fogging activity was done between $0400 \mathrm{~h}$ and $0430 \mathrm{~h}$ (lasting approximately 1:30 $\mathrm{min}$ ) in order to avoid denaturalization of the insecticide by solar radiation, avoiding windy or rainy days. Arthropods fallen from each fogged tree were collected in ten plastic trays $\left(1 \mathrm{~m}^{2}\right.$ area per tray) that were randomly distributed under tree crowns. The arthropods were kept in $70 \%$ ethanol except adult organisms of Lepidoptera, which were kept in glassine paper bags. The arthropods were separated into morphospecies. Abundance of each 
morphospecies was also counted. In this study, 'arthropod morphospecies' will be referred as 'arthropod species.'

\section{Molecular data}

Leaves with no apparent damage were collected from ten individuals of Q. crassifolia in each forest type. Total DNA was extracted and purified by using the DNAeasy Plant Mini Kit (Qiagen, Valencia, CA, USA). DNA quantification was done by fluorometric analysis (Eppendorf, Biophotometer, Hamburg, Germany), and DNA quality was visualized by comparing the intensity of bands with known standards of lambda DNA on agarose gels at $0.8 \%$. Genetic analyses were performed using nuclear microsatellite markers (nSSRs).

We chose six nuclear microsatellites primers (OC11, OE09, CO8, FO7, QpZAG110, and QrZAG11) that detected polymorphisms in Q. crassifolia. Forward primers were labeled with a fluorescent tag: HEX (green), NED (yellow), or FAM (blue). PCR reactions were done as follows: $15 \mathrm{ng}$ of DNA template, $50 \mathrm{mM} \mathrm{KCl}, 20 \mathrm{mM}$ Tris- $\mathrm{HCl}$ (pH 8.4), $2 \mathrm{mM} \mathrm{MgCl}_{2}, 0.13 \mathrm{mM}$ of each dNTP, $25 \mathrm{mM}$ of each primer, and $0.8 \mathrm{U}$ of Taq polymerase, in a final volume of $15 \mu \mathrm{l}$. Reaction conditions were as follows: an initial denaturation step at $95^{\circ} \mathrm{C}$ for $5 \mathrm{~min}$, followed by 30 cycles at $94^{\circ} \mathrm{C}$ for $1 \mathrm{~min}, 1 \mathrm{~min}$ at the appropriate annealing temperature, followed by 30 $\mathrm{s}$ at $72^{\circ} \mathrm{C}$, and a final extension step at $72^{\circ} \mathrm{C}$ for $8 \mathrm{~min}$. Annealing temperature differed for each primer pair: $53^{\circ} \mathrm{C}$ for $\mathrm{OC} 11$ and $\mathrm{OE} 09,50^{\circ} \mathrm{C}$ for $\mathrm{CO} 8,58^{\circ} \mathrm{C}$ for $\mathrm{FO} 7$, $48^{\circ} \mathrm{C}$ for QpZag 110 , and $53^{\circ} \mathrm{C}$ for QrZag 11 . PCR products were resolved on agarose gels at $2 \%$ to $180 \mathrm{~V}$ for $1.5 \mathrm{~h}$. Depending on the strength of the bands on the agarose test gel, these were diluted 1:10 to $1: 90$ with water. Polymorphic fragments were sequenced on an automatic sequencer ABI-PRISM 3100 (Applied Biosystems Inc., Foster City, CA, USA) using $9.5 \mathrm{ml}$ of formamide, $0.5 \mathrm{ml}$ of ROX 500 used as a size standard, and $1 \mathrm{ml}$ of each PCR product. Alleles were scored using the Gene Mapper ver. 3.7 Software (Applied Biosystems, Foster City, CA, USA).

\section{Statistical analysis}

Three-factor ANOVAs were conducted (model type III, Zar 2010) to determine the effect of forest type (Quercus, Quercus-Pinus, and Abies-Quercus), season (dry and rainy), individual genetic relatedness of host plant (internal relatedness (IR)), and interaction of forest type $\times$ season on canopy arthropod density. Density values of canopy arthropods were log-transformed $\left(X^{\prime}=\log _{\mathrm{e}} X+1\right)$ (Zar 2010). Two-factor ANOVAs were conducted (model type III, Zar 2010) to determine the effect of forest type (Quercus, Quercus-Pinus, and Abies-Quercus), season (dry and rainy), and interaction of forest type $\times$ season on canopy arthropod diversity and richness species.
Differences in canopy arthropod species composition between forest types were tested using non-metric multidimensional scaling (NMDS) based on the presence of 422 arthropod species. NMDS is a robust ordination technique for community analysis. NMDS was used to generate a dissimilarity matrix between forest types by season using the Bray-Curtis dissimilarity coefficient. Differences in canopy arthropod community species composition between forest types were quantified with the Bray-Curtis similarity coefficient that was calculated on the square roottransformed species by sample abundance data matrix.

Analysis of similarity (ANOSIM) was used to evaluate the differences between arthropod community composition and forest type by season. ANOSIM was employed to test for differences among groups using 1,000 random reassignments and determining whether the generated dissimilarity matrix is significantly different than chance (Warwick et al. 1990).

The diversity of canopy arthropod community associated to Q. crassifolia at each oak tree was estimated using the true Shannon diversity index $\left(\exp \left(\mathrm{H}^{\prime}\right)\right)$ (Jost 2006). Thereafter, the index was compared between forest types with a randomization test as described by Solow (1993), this test re-samples 10,000 times from a distribution of species abundances produced by a summation of the two samples.

Individual genetic relatedness of $Q$. crassifolia was quantified using the IR parameter (Amos et al. 2001). IR is based on the relatedness measure of Queller and Goodnigth (1989), except that at each locus, two alleles rather than two pairs of alleles are compared. Over several loci, the resulting values are approximately normally distributed and centered on zero, with negative values suggesting relatively outbred individuals and high positive values being suggestive of inbreeding. IR values were computed using EXCEL (Microsoft INC.) macro written in Visual Basic provided on the William Amos website (http://www.zoo.cam.ac.uk/dir ectory/william-amos, Department of Zoology, Cambridge University, UK). For this study, IR values were multiplied by (-). Thus, IR values below zero denote inbred individuals and values above zero denote outbred individuals. Diversity index $\left(H^{\prime}\right)$ and species richness $(S)$ variables were correlated with each other. Therefore, the relationship between individual genetic relatedness of $Q$. crassifolia in each forest type and the arthropod $H^{\prime}$ was tested by regression analyses.

The softwares used for statistical analysis were STATISTICA 8.0 (StatSoft Inc 2007), Species Diversity and Richness 3.03 (Henderson and Seaby 2002), and PCORD 4.28 (McCune and Mefford 1999).

\section{Results}

\section{Composition of arthropods}

In total, 17,485 individuals were collected, 15,073 during rainy and 2,412 during dry season. Canopy arthropod 
composition of Q. crassifolia is formed by 422 species belonging to 22 orders (Araneae, Arthropleona, Astigmata, Coleoptera, Cryptostigmata, Dermaptera, Diptera, Hemiptera, Hymenoptera, Isoptera, Lepidoptera, Mecoptera, Mesostigmata, Neuroptera, Opiliones, Orthoptera, Pseudoscorpiones, Prostigmata, Psocoptera, Symphypleona, Thysanoptera, and Trichoptera).

Relative abundance of species grouped into arthropod orders changed between seasons and between forest types (Figure 1). During dry season, the most abundant groups were Hymenoptera, Cryptostigmata, and Diptera, whereas Arthropleona, Coleoptera, and Cryptostigmata were the most common groups during rainy season, independently of the forest type (Figure 1). For forest type, Cryptostigmata, Arthropleona, and Hemiptera were the most common groups in Quercus forest, whereas
Arthropleona, Coleoptera, and Cryptostigmata were the most abundant groups in Quercus-Pinus forest. Finally, Hymenoptera, Cryptostigmata, and Coleoptera were the most common groups in Abies-Quercus forest (Figure 1).

In general, we found significant differences in canopy arthropod community composition associated to Q. crassifolia among forest types (ANOSIM $R=0.4823$, $n=39, P<0.001$ ) (Figure 2), being these communities significantly different from one another on all three forest types. Within a forest type, we found significant differences in canopy arthropod community composition between different seasons, also, the differences among categories (forest types) were significant after correcting the critical value of alpha for inflated type II errors ( $P<0.02$ for all comparisons) (Quercus: ANOSIM $R=$ 0.4802, $P<0.001$; Quercus-Pinus: ANOSIM $R=0.5137$,

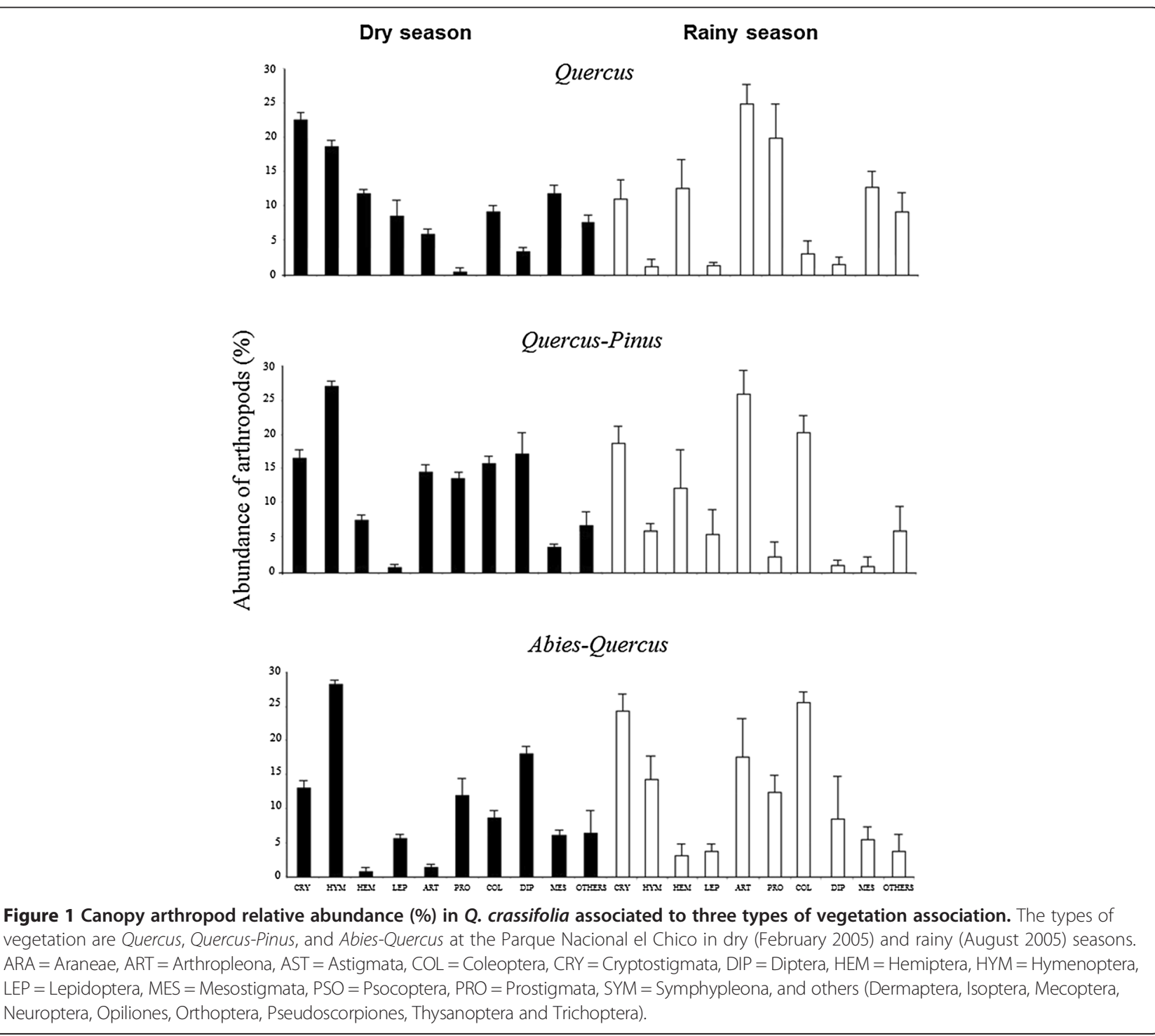




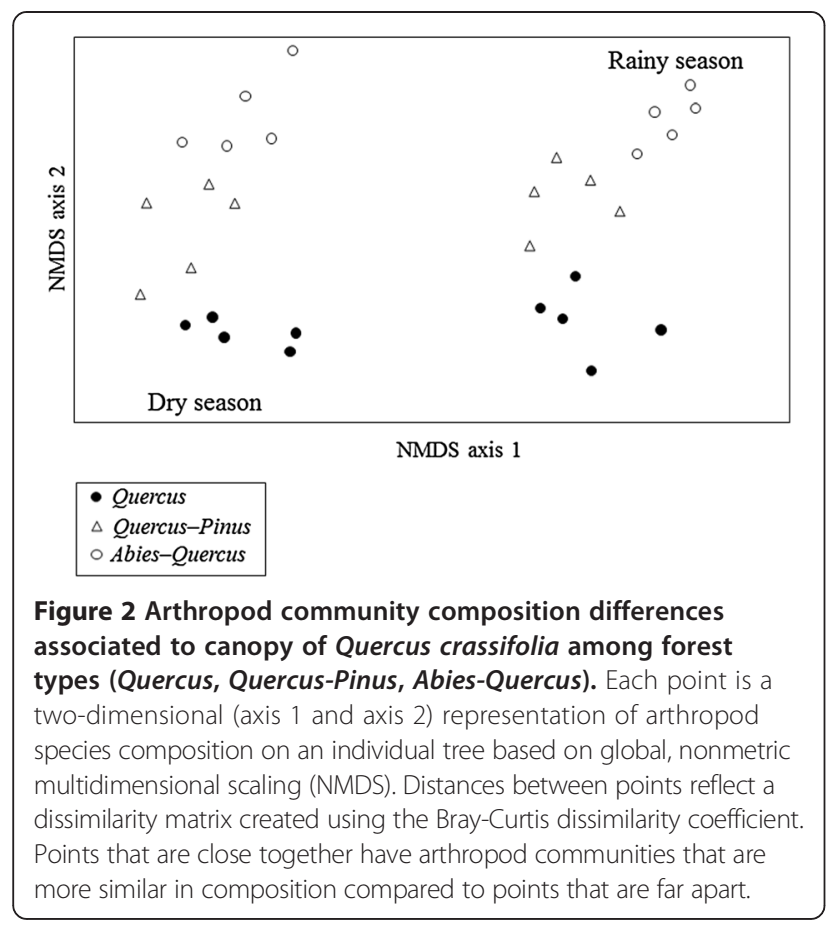

$P<0.001$; Abies-Quercus: ANOSIM $R=0.6330, P<0.001$ ). Therefore, these results indicate that canopy arthropod community composition varies in space and time.

\section{Density of arthropods}

The density of canopy arthropod species differed significantly between individual genetic relatedness $\left(F_{24,270}=\right.$ 8.26, $P<0.001)$, forest types $\left(F_{2,270}=6.93, P<0.01\right)$, seasons $\left(F_{1,270}=187.07, P<0.001\right)$ and interaction season $\times$ forest types $\left(F_{2,270}=4.99 P<0.01\right)$. In general, we found that canopy arthropod densities associated to $Q$. crassifolia showed the following pattern: Abies-Quercus $<$ QuercusPinus < Quercus for both seasons. The results showed that in each forest type, the arthropod densities increased between 4.9 and 5.9 times higher during rainy than dry season (Table 1).

\section{Diversity of arthropods}

The richness of canopy arthropod species differed significantly between forest types $\left(F_{2,24}=53.64, P<0.001\right)$, seasons $\left(F_{1,24}=648.12, P<0.001\right)$, and interaction season $\times$ forest type $\left(F_{2,24}=175.63, P<0.001\right)$. On the other side, the diversity of canopy arthropod species did not differed significantly between forest type $\left(F_{2,24}=1.93, P>0.05\right)$ and interaction season $\times$ forest type $\left(F_{2,24}=1.44, P>0.05\right)$, in contrast, significant differences between seasons were registered $\left(F_{1,24}=50.91, P<0.001\right)$.

In this study, we found that $H^{\prime}$ and $S$ of canopy arthropods associated to $Q$. crassifolia showed the following pattern, according to forest type: Abies-Quercus [ $S=209$; $\left.\exp \left(H^{\prime}\right)=148\right]>$ Quercus-Pinus $\left[S=143 ; \exp \left(H^{\prime}\right)=81\right]>$
Quercus [ $S=116 ; \exp \left(H^{\prime}\right)=55$ ] (Table 2). In addition, the highest values of $H^{\prime}$ and $S$ were found during rainy season for the three forest types: Abies-Quercus $>$ QuercusPinus > Quercus (Table 2).

\section{Relationship between oak host plant genetic relatedness and canopy arthropod community}

This study revealed that host plant IR affects significantly the diversity of canopy arthropods $\left(H^{\prime}\right)$. In general, our results showed a positive and significant relationship between genetic relatedness of $Q$. crassifolia and the diversity of canopy arthropods in dry $\left(r=0.66, F_{1,13}=\right.$ $10.17, P<0.01)$ and rainy season $\left(r=0.73, F_{1,13}=14.86\right.$, $P<0.01$ ) (Figure 3).

\section{Discussion}

The results obtained in the present study showed that the forest type had a significant effect on canopy arthropod community structure of Q. crassifolia. We found a different community structure among forest types in terms of composition. Also, the values of $H^{\prime}, S$, and density of arthropod fauna were higher during rainy season for the three forest types. In general, $H^{\prime}$ and $S$ of arthropods showed the following pattern: Abies-Quercus $>$ QuercusPinus $>$ Quercus. Surprisingly, the density showed an inverse pattern (Abies-Quercus $<$ Quercus-Pinus $<$ Quercus). Finally, an increase of the host plant genetic diversity was significantly related to an increase of canopy arthropod diversity, independently of the forest type and season.

\section{Effect of forest type and season on canopy arthropod community}

Our results showed that the forest type has a significant effect on canopy arthropod community structure of $Q$. crassifolia. We found a different community structure among forest types in terms of composition, density, $S$, and $H^{\prime}$. In general, Hymenoptera, Cryptostigmata, and Diptera were the most abundant groups collected in $Q$. crassifolia canopies during dry season. Also, we found that the majority of Hymenoptera species corresponded to the Cynipidae family, which is highly specialized to the Quercus genus (Stone et al. 2002). The fact that Cynipidae populations increase during dry season is probably related to its oviposition behavior or eclosion processes (Stone et al. 2002).

In our collection, Cryptostigmata was one of the most abundant groups in both seasons. These results are similar to other studies in tropical (Palacios-Vargas and Castaño-Meneses 2003) and temperate (Tovar-Sánchez 2009) forests in Mexico. Probably, the presence of arboreal epiphytes and rugose cortex (which accumulates organic matter) of Q. crassifolia, mainly during rainy season, favors an increase of resources and conditions that can be exploited by these organisms (Palacios-Vargas and 
Table 1 Density (no. ind./ $\mathrm{m}^{2} \pm \mathrm{SE}$ ) of canopy arthropods associated to $Q$. crassifolia by forest type

\begin{tabular}{|c|c|c|c|c|c|c|}
\hline \multirow[t]{3}{*}{ Tree } & \multicolumn{6}{|c|}{ Forest type } \\
\hline & \multicolumn{2}{|c|}{ Quercus } & \multicolumn{2}{|c|}{ Quercus-Pinus } & \multicolumn{2}{|c|}{ Abies-Quercus } \\
\hline & Dry & Rainy & Dry & Rainy & Dry & Rainy \\
\hline 1 & $29.5 \pm 3.2$ & $123.2 \pm 8.9$ & $17.8 \pm 2.5$ & $137.6 \pm 14.5$ & $20.1 \pm 2.8$ & $90.8 \pm 11.4$ \\
\hline 2 & $37.4 \pm 4.1$ & $238.2 \pm 12.3$ & $25.0 \pm 3.3$ & $105.3 \pm 20.2$ & $24.7 \pm 3.6$ & $105.3 \pm 10.6$ \\
\hline 3 & $39.7 \pm 5.3$ & $175.9 \pm 20.1$ & $27.3 \pm 4.1$ & $138.5 \pm 17.3$ & $13.7 \pm 2.3$ & $112.4 \pm 13.2$ \\
\hline 4 & $45.2 \pm 3.6$ & $129.8 \pm 19.0$ & $30.6 \pm 3.8$ & $98.3 \pm 9.7$ & $17.4 \pm 2.7$ & $89.5 \pm 8.3$ \\
\hline 5 & $28.6 \pm 3.9$ & $144.5 \pm 18.3$ & $23.3 \pm 3.4$ & $165.7 \pm 31.4$ & $14.3 \pm 3.0$ & $132.7 \pm 12.3$ \\
\hline \multirow[t]{2}{*}{ Total } & $33.1 \pm 3.0$ & $162.3 \pm 9.3$ & $24.8 \pm 3.2$ & $129.9 \pm 16.7$ & $18.0 \pm 2.6$ & $106.1 \pm 10.3$ \\
\hline & $a$ & $A$ & $b$ & $B$ & c & C \\
\hline
\end{tabular}

Data from dry (February 2005) and rainy seasons (August 2005). Italicized data indicated the values of the maximum and minimum densities per season. Different letters show significant differences $P<0.05$ (Tukey test). Capital letters show significant differences between forest type in rainy season and lower case letters in dry season.

Castaño-Meneses 2003). The abundance of Cryptostigmata in each forest type registered the following pattern: Abies-Quercus > Quercus-Pinus > Quercus. This pattern is related to the number of arboreal species growing in sympatry with $Q$. crassifolia in each forest type, a phenomenon that is known as 'associational susceptibility' (White and Whitham 2000), in which plant species present greater abundance of herbivores when spatially associated with heterospecific neighbors (White and Whitham 2000).

On the other hand, Arthropleona, Coleoptera, and Cryptostigmata were the most abundant groups in the different forest types during rainy season. We suggest that the high abundance of Arthropleona may be due to its small body size and preference to humid habitats. Probably, the augment of the water availability and organic matter concentration in canopies during rainy season promoted an increase of conditions and resources that allowed the increase of their population size (Castaño-Meneses 2002). Contrary to the results obtained for Cryptostigmata, these results do not support the 'associational susceptibility' hypothesis, because Arthropleona, was more abundant in the Quercus forest, followed by Quercus-Pinus and Abies-Quercus.
We found that Coleoptera was a very abundant group during rainy season (Abies-Quercus $>$ Quercus-Pinus > Quercus). Barbosa et al. (2000) suggested that during this season, there is an increase in resource availability, which is in accordance with seasonal growth of forest ecosystems. In this sense, Romero et al. (2002) document that Q. crassifolia is a deciduous species, which increases branch, leaves, and fruit formation and development of epiphyte plants, a fact that can favor a great possibility of resources that may be used by canopy arthropods (Tovar-Sánchez et al. 2003). Also, during rainy season, younger leaves are more abundant, nutritive, and softer and have less secondary metabolites (Coley et al. 2006). An increase in host plant nutritional quality as well as the availability of canopy resources may explain the proliferation of phytophagous beetles associated to $Q$. crassifolia canopies at the PNECh during rainy season. Similar results were observed by Wagner (2000) in the canopy of Rinorea beniensis in a rainy forest in Uganda. Moreover, the results obtained for the order Coleoptera support the associational susceptibility hypothesis.

In addition, we found that $H^{\prime}$ and $S$ of canopy arthropods showed the following pattern: Abies-Quercus $>$ Quercus-

Table 2 Shannon-Wiener diversity index $\left(\exp \left(H^{\prime}\right)\right)$ and species richness $(S)$ of the communities of canopy arthropods

\begin{tabular}{|c|c|c|c|c|c|c|c|c|c|c|c|c|}
\hline \multirow[t]{4}{*}{ Tree } & \multicolumn{12}{|c|}{ Forest type } \\
\hline & \multicolumn{4}{|c|}{ Quercus } & \multicolumn{4}{|c|}{ Quercus-Pinus } & \multicolumn{4}{|c|}{ Abies-Quercus } \\
\hline & \multicolumn{2}{|c|}{ Dry } & \multicolumn{2}{|c|}{ Rainy } & \multicolumn{2}{|c|}{ Dry } & \multicolumn{2}{|c|}{ Rainy } & \multicolumn{2}{|c|}{ Dry } & \multicolumn{2}{|c|}{ Rainy } \\
\hline & $S$ & $\operatorname{Exp}\left(H^{\prime}\right)$ & $S$ & $\operatorname{Exp}\left(H^{\prime}\right)$ & $S$ & $\operatorname{Exp}\left(H^{\prime}\right)$ & $S$ & $\operatorname{Exp}\left(H^{\prime}\right)$ & $S$ & $\operatorname{Exp}\left(H^{\prime}\right)$ & $S$ & $\operatorname{Exp}\left(H^{\prime}\right)$ \\
\hline 1 & 13 & 14.88 & 38 & 40.44 & 33 & 22.20 & 54 & 36.95 & 32 & 24.53 & 77 & 29.96 \\
\hline 2 & 11 & 16.44 & 43 & 22.19 & 15 & 30.26 & 66 & 44.70 & 44 & 60.34 & 83 & 33.11 \\
\hline 3 & 15 & 8.17 & 41 & 47.94 & 18 & 7.84 & 49 & 81.45 & 42 & 29.96 & 70 & 99.48 \\
\hline 4 & 9 & 5.47 & 36 & 11.02 & 16 & 22.20 & 51 & 66.68 & 33 & 14.88 & 84 & 46.52 \\
\hline 5 & 13 & 7.39 & 49 & 32.45 & 20 & 18.17 & 53 & 68.72 & 38 & 17.63 & 73 & 47.94 \\
\hline Total & 26 & 18.17 & 90 & 49.40 & 40 & 33.12 & 126 & 66.7 & 53 & 40.44 & 157 & 109.94 \\
\hline
\end{tabular}

Associated to Q. crassifolia in three forest types (Quercus, Quercus-Pinus, Abies-Quercus) at the Parque Nacional el Chico, Hidalgo, during dry (February 2005) and rainy (August 2005) seasons. Italicized data indicated the values of the maximum and minimum diversity index and species richness per season. 


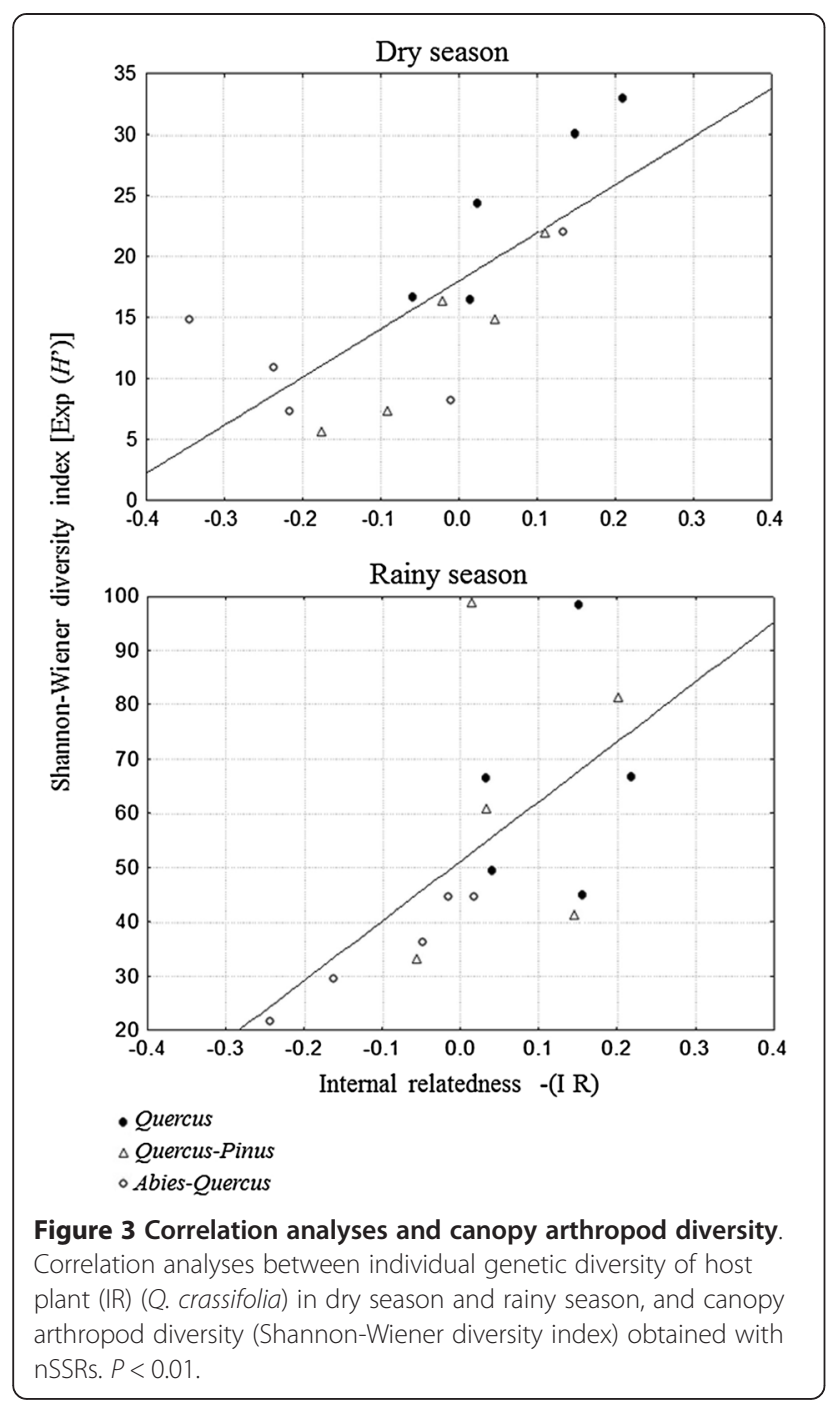

Pinus $>$ Quercus. This pattern is consistent with a gradient of tree species among forest types: Abies-Quercus $(n=16)$ $>$ Quercus-Pinus $(n=11)>$ Quercus $(n=7)$, supporting once more the 'associational susceptibility' hypothesis.

In habitats such as temperate forests, tree communities are a key element for shaping the environmental physical structure. For this reason, it has been suggested that tree species richness could influence an increase in richness and abundance of canopy arthropod fauna (Lassau et al. 2005). The aforementioned pattern is also supported by the results obtained by Castaño-Meneses (2002) who evaluated the spatial distribution of the epiphyte plant Tillandsia violaceae inside the PNECh. The author found a major density of $T$. violaceae in AbiesQuercus forest. This information supports our field observations, where the epiphyte $T$. violaceae increases its density in the following gradient: Abies-Quercus > QuercusPinus $>$ Quercus. Therefore, we propose that an increase in epiphyte abundance favors a greater heterogeneity of resources and conditions in the canopy of Q. crassifolia. Therefore, habitat heterogeneity predicts that structurally more complex habitats can offer a wider array of resources and conditions, which will favor more species diversity in the communities (Affeld 2008). Hence, we propose that the gradient observed for canopy arthropods associated to Q. crassifolia is a response to habitat heterogeneity, motivated by the richness of tree species, heterospecific neighbors (associational susceptibility, White and Whitham 2000) and epiphyte density among forest types.

Density, $S$, and $H^{\prime}$ values of arthropods in the different forest types were higher during rainy season. These results are similar to those reported for other temperate forests in Mexico (Tovar-Sánchez et al. 2003; Tovar-Sánchez and Oyama 2006a, b; Tovar-Sánchez 2009). It has been proposed that this pattern may be the result of an increase in resource availability during rainy season, which is in accordance with this season major productivity of forest ecosystems (Barbosa et al. 2000).

In general, associated arthropod communities to different oak species are composed mainly of generalist species. Although these communities appear to be generalists, it has been documented that the taxonomic status of host-trees may be an important factor in the arthropod community structure (Tovar-Sánchez et al. 2003, TovarSánchez and Oyama 2006a). In particular, special attention has been paid to gall forming (Cynipidae: Hymenoptera) and leaf mining insects (Lepidoptera: Tischeridae, Citheraniidae). Oak gall wasps are obligate parasites and are considered as organ-species-specific. Mexico has the greatest richness of oak gall wasps, with approximately 700 species included in 29 genera (Wendel 1960). Studies of the Cynipidae family in hybrid zones of Quercus crassipes $\times$ Q. crassifolia complex have shown that gall wasps are highly sensitive to host plant genetic diversity levels (Tovar-Sánchez and Oyama 2006b). Valuable insights into these processes can be gained through the investigation of distribution, abundance, and diversity of canopy insects in response to genetic diversity.

\section{Effect of host plant genetic relatedness on canopy arthropod community}

Our results showed that as the individual genetic relatedness (IR) of Q. crassifolia increases, the values of $H^{\prime}$ of the canopy arthropod communities also increases, independent of the forest type or season. In particular, during dry season, the IR of Q. crassifolia explains $44 \%$ of canopy arthropod diversity. Whereas, during rainy season, the IR of Q. crassifolia explains 53\% of the canopy arthropod diversity. These results are consistent with those reported by Tovar-Sánchez et al. (2013), who found that an increase in IR levels of Q. crassipes and Quercus castanea favors $H^{\prime}, S$, and density of canopy arthropods. Specifically, 
their results of $I R$ vs. $H^{\prime}$ explained from $56 \%$ to $73 \%$ of the variation for Q. crassipes and from $68 \%$ to $84 \%$ for Q. castanea. Likewise, Wimp et al. (2004) found that the cottonwoods genetic diversity (Populus fremontii $\times$ Populus angustifolia) is positively and significantly related to the diversity $\left(H^{\prime}\right)$ of their endophagous insect community, explaining about $60 \%$ of the variability in the community. Similarly, Tovar-Sánchez and Oyama (2006b) reported that the oak genetic diversity (Quercus crassipes $\times Q$. crassifolia) explained about $78 \%$ of the diversity $\left(H^{\prime}\right)$ of their endophagous insect community. However, in both studies, genetic diversity was measured at the population level. The results obtained by these studies show that canopy arthropod communities respond to the genetic diversity of host plant, independent of the biological organization level where it is measured.

In this study, we evaluated the genetic relatedness of the host plant in different forest types in one locality, this experimental design allowed us to control variables that have been documented as factors that modify the arthropod community structure. For example, forest age (Marquis et al. 2000), altitude (Summerville et al. 2003), soil type (Gering et al. 2003), climate (Price et al. 2004), and disturbances (Tovar-Sánchez et al. 2003) and spatial location (Tack et al. 2010) are among others.

Host plant genetic relatedness not only has a direct impact on their herbivore community, because its effects can be extended to higher trophic levels indirectly, by promoting a cascade effect throughout the community (Whitham et al. 2006). For example, an increase in host plant genetic diversity can promote an augment in their architectural complexity and nutritional quality (Bangert et al. 2005). This may favor herbivore density, predation intensity, and parasitism degree (Whitham et al. 2006).

These studies have suggested that the areas with more genetically diverse host plant species can be considered as centers of species diversity (Tovar-Sánchez and Oyama 2006a), areas of great ecological and evolutionary activity, providing new habitats for associated communities.

\section{Conclusions}

Recently, a genetic approach has revealed that the influence of genetic diversity in foundation species extends to the community and ecosystem levels. Our results demonstrate that the forest type and genetic relatedness of host plants have a significant effect on the canopy arthropod community structure. Interestingly, genetic diversity effect is presented in a consistent manner, regardless of forest type and season. It is now important to demonstrate these effects in other foundation species and in other spatial scales to understand their generality.

From a conservation perspective, maintaining genetic diversity of host plants and arboreal plant communities richer in species is crucial for the preservation of associated arthropod species. Also, it is a priority to assign a new conservation status to foundation species and propose strategies to safeguard mechanism to maintain their diversity. This serves as a guide for future conservation efforts and provides a mechanism of why conservation efforts may fail if they do not consider the community consequences of genetic variation in foundation species, because their extended phenotypes affect the rest of the community. Because oaks represent dominant trees in Mexican temperate forests, these findings may be important locally and at a landscape level. The development of a community genetic perspective should help us to understand the natural world, its complex interactions, and the effects of anthropogenic change.

\section{Competing interests}

The authors declare that they have no competing interests.

\section{Authors' contributions}

All authors participated in the review topic design, in the data analyses, and in the manuscript writing. T-SE: participated in experimental design, field work, data analyses and in the manuscript writing. M-FE: participated in field work and in arthropod determination. V-CL: participated in the manuscript writing and statistical analysis. M-GP: participated in the manuscript writing and statistical analysis. All authors read and approved the final version of the manuscript.

\section{Acknowledgements}

We thank the specialists on arthropod and plant taxonomy for their interest and assistance in this project: S. Valencia-Avalos (Oaks), C. Mayorga (Hemiptera), G. Ortega-León (Hemiptera), B. Mejía and A. Hernández (Arthropleona, Astigmata, Cryptostigmata, Mesostigmata, Prostigmata, and Symphypleona), A. Godínez (Diptera), Zaragoza (Coleoptera), O. Ávalos (Diptera and Hymenoptera), P. Hernández (Hymenoptera), M. Menéndez (Araneae), and A. Ibarra Vázquez (Lepidoptera). We thank L. Marquez-Valdemar, Gabriel Flores-Franco, and G. Rangel-Altamirano for their technical assistance. Also, we thank A. Callejas for the criticisms and suggestions to improve the manuscript. This research was supported by grants from the CONACYT-Mexico (61725) to E.T.S.

\section{Author details}

1Departamento de Sistemática y Evolución, Centro de Investigación en Biodiversidad y Conservación, Universidad Autónoma del Estado de Morelos, Av. Universidad 1001, Col. Chamilpa, Morelos, Cuernavaca CP 62209, Mexico. ¿2aboratorio de Investigaciones Ambientales, Centro de Investigación en Biotecnología, Universidad Autónoma del Estado de Morelos, Av. Universidad 1001, Col. Chamilpa, Morelos, Cuernavaca CP 62209, Mexico.

Received: 15 November 2014 Accepted: 16 March 2015

Published online: 24 March 2015

\section{References}

Affeld K (2008) Spatial complexity and microclimatic responses of epiphyte communities and their invertebrate fauna in the canopy of northern rata (Metrosideros robusta A. Cunn.: Myrtaceae) on the West Coast of the South Island, New Zealand. Dissertation, Lincoln University

Amos W, Worthington J, Fullard K, Burg TM, Croxalli JP, Bloch D, Coulson T (2001) The influence of parental relatedness on reproductive success. Proc $R$ Soc Lond B 268:2021-2028

Bailey JK, Whitham TG (2007) Biodiversity is related to indirect interactions among species of large effect. In: Ohgushi T, Craig T, Price PW (eds) Indirect interactions webs: nontrophic linkages through induced plant traits. Cambridge University Press, Cambridge

Bangert RK, Turek RJ, Martinsen GD, Wimp GM, Bailey JK, Whitham TG (2005) Benefits of conservation of plant genetic diversity on arthropod diversity. Conserv Biol 19:379-390 
Barbosa P, Segarra A, Gross P (2000) Structure of two macrolepidopteran assemblages on Salix nigra (Marsh) and Acer negundo L.: abundance, diversity, richness, and persistence of scarce species. Ecol Entomol 25:374-379

Castaño-Meneses RG (2002) Estructura de la comunidad de artrópodos epífitos y su papel en el crecimiento de Tillandsia violacea (Bromeliaceae) en un bosque templado de Hidalgo, México. Dissertation, Universidad Nacional Autónoma de México

Coley PD, Bateman LM, Kursar A (2006) The effects of plant quality on caterpillar growth and defense against natural enemies. Oikos 115:218-228

CONANP (2006) Anteproyecto Programa de Conservación y Manejo Parque Nacional el Chico. CONANP, Mexico

Dayton PK (1972) Toward an understanding of community resilience and the potential effects of enrichments to the benthos at McMurdo Sound, Antarctica. In: Parker BC (ed) Proceedings of the colloquium on conservation problems in Antarctica. Allen Press, Lawrence

Dungey HS, Potts BM, Whitham TG, Li HF (2000) Plant genetics affects arthropod community richness and composition: evidence from a synthetic eucalypt hybrid population. Evolution 54:1938-1946

Dutech C, Sork VL, Irwin AJ, Smousse P, Davis FW (2005) Gene flow and fine-scale genetic structure in a wind-pollinated tree species, Quercus lobata (Fagaceae). Am J Bot 92:252-261

FAO (2006) Global forest resources assessment: progress towards a sustainable forest management. Forest Paper 147, Italy

Ferrier SM, Bangert RK, Hersch-Green E, Bailey JK, Allan GJ, Whitham TG (2012) Unique arthropod communities on different host-plant genotypes results in greater arthropod diversity. Arthropod-Plant Interact 6:187-195

Gering JC, Veech JA, Crist TO (2003) Additive partitioning of species diversity across multiple spatial scales: implications for regional conservation of biodiversity. Conserv Biol 17:488-499

Hamilton AJ, Basset Y, Benke KK, Grimbacher PS, Miller SA, Novotny V, Samuelson GA, Stork NE, Weiblen GD, Yen JDL (2010) Quantifying uncertainty in estimation of tropical arthropod species richness. Am Nat 176:90-95

Henderson PA, Seaby MPH (2002) Species diversity and richness software 3.03. Pisces Conservation Ltd, Lymington, UK

Hochwender CG, Fritz RS (2004) Plant genetic differences influence herbivore community structure evidence from a hybrid willow system. Oecologia 138:547-557

Jost L (2006) Entropy and diversity. Oikos 113:363-375

Lassau SA, Hochuli DF, Cassis G, Reid CAM (2005) Effects of habitats complexity of forest beetle diversity: do functional groups respond consistently? Divers Distrib 11:73-82

Leather SR, Basset Y, Hawkins BA (2008) Insect conservation: finding the way forward. Insect Conserv Diver 1:67-69

Madritch MD, Hunter MD (2002) Phenotypic diversity influences ecosystem functioning in an oak sandhills community. Ecology 83:2084-2090

Marquis RJ, Forkner RE, Lill J, Le Corff J (2000) Impact of timber harvest on species accumulation curves for oak herbivore communities of the Missouri Ozarks. In: Brookshire B, Shifley S (eds) Proceedings of the second Missouri Ozark Forest Ecosystem project symposium. Missouri Ozark Forest Ecosystem Project (MOFEP), Minnesota

Mccune B, Mefford MJ (1999) PC-ORD. Multivariate analysis of ecological data, version 4.28. MjM Software. Gleneden Beach, Oregon, USA

Nadkarni NM, Parker GG, Rinker HB, Jarzen DM (2004) The Nature of forest canopies. In: Lowman ED, Rinker HB (eds) Forest canopies. Elsevier Academic Press, San Diego

Palacios-Vargas JG, Castaño-Meneses G (2003) Seasonality and community composition of springtails in Mexican forest. In: Basset $Y$, Novotny V, Miller $S$, Kitching RL (eds) Arthropods of tropical forest: spatio-temporal dynamics and resource use in the canopy. Chapman and Hall, London

Price PW, Abrahamson WG, Hunter MD, Melika G (2004) Using gall wasps on oaks to test broad ecological concepts. Conserv Biol 18:1405-1416

Queller DG, Goodnigth KE (1989) Estimating relatedness using genetic markers. Evolution 43:258-275

Romero S, Rojas E, Aguilar M (2002) El género Quercus (Fagaceae) en el Estado de México. Ann Mo Bot Gard 89:551-593

Sobek S, Steffan-Dewenter I, Scherber C, Tschamtke T (2009) Spatiotemporal changes of beetle communities across a tree diversity gradient. Divers Distrib 15:660-670

Solow RA (1993) A simple test for change in community structure. J Anim Ecol 62:191-193

Inc SS (2007) STATISTICA for Windows. Tulsa, USA
Stone GN, Schönrogge K, Atkinson RJ, Bellido D, Pujade-Villar J (2002) The population biology of oak gall wasps (Hymenoptera: Cynipidae). Ann Rev Entomol 47:633-688

Stork NE (1998) Insect diversity: facts, fiction and speculation. Biol J Linn Soc 35:321-337

Stork NE, Hammond PM (1997) Sampling arthropods from tree-crowns by fogging with knockdown insecticides: lessons from studies of oak tree beetle assemblages in Richmond Park (UK). In: Stork NE, Adis J, Didham PK (eds) Canopy arthropods. Chapman and Hall, London

Summerville KS, Boulware MJ, Veech JA, Crist TO (2003) Spatial variation in species diversity and composition of forest Lepidoptera in eastern deciduous forest of North America. Conserv Biol 17:1045-1057

Tack AJ, Ovaskainen O, Pertti P, Roslin T (2010) Spatial location dominates over host plant genotype in structuring an herbivore community. Ecology 91:2660-2672

Tack AJ, Roslin T (2011) The relative importance of host-plant genetic diversity in structuring the associated herbivore community. Ecology 92:1594-1604

Tovar-Sánchez E (2009) Canopy arthropods community within and among oak species in central Mexico. Acta Zool Sinica 55:132-144

Tovar-Sánchez E, Oyama K (2006a) Community structure of canopy arthropods associated to Quercus crassifolia × Quercus crassipes complex. Oikos 112:370-381

Tovar-Sánchez E, Oyama K (2006b) Effect of hybridization of the Quercus crassifolia $\times$ Quercus crassipes complex on the community structure on endophagous insects. Oecologia 147:702-713

Tovar-Sánchez E, Cano Z, Oyama K (2003) Canopy arthropod on Mexican oaks at sites with different disturbance regimes. Biol Conserv 115:79-87

Tovar-Sánchez E, Valencia-Cuevas L, Castillo-Mendoza E, Mussali-Galante P, Pérez-Ruiz RV, Mendoza A (2013) Association between individual genetic diversity of two oak host species and canopy arthropod community structure. Eur J For Res 132:165-179

Valencia S (2004) Diversidad del género Quercus (Fagaceae) en México. Bol Soc Bot Méx 75:33-53

Wagner T (2000) Influence of forest type and tree species on canopy-dwelling beetles in Budongo forest Uganda. Biotropica 32:502-514

Warwick RM, Clarke KR, Suharsono A (1990) A statistical analysis of coral community responses to the 1982-1983 El Niño in the Thousand Island, Indonesia. Coral Reefs 8:171-179

Wendel LH (1960) Cynipid galls of the Southwest. Privately Printed, Ann Arbor, Michigan

White JA, Whitham TG (2000) Associational susceptibility of cottonwood to a box elder herbivore. Ecology 81:1795-1803

Whitham TG, Bailey JK, Scheweitzer JA, Shuster SM, Bangert RK, LeRoy CJ, Lonsdorf EV, Allan GJ, DiFazio SP, Potts BM, Fischer DG, Gehring CA, Lindroth RL, Marks JC, Hart SC, Wimp GM, Wooley SC (2006) A framework for community and ecosystem genetics: form genes to ecosystems. Nat Rev Genet 7:510-523

Wimp GM, Young PW, Woolbright SA, Martinsen GD, Keim P, Whitham TG (2004) Conserving plant genetic diversity for dependent animal communities. Ecol Lett 7:776-780

Zar JH (2010) Biostatystical analysis. Prentice-Hall Inc., New Jersey, USA

\section{Submit your manuscript to a SpringerOpen ${ }^{\odot}$ journal and benefit from:}

- Convenient online submission

- Rigorous peer review

- Immediate publication on acceptance

- Open access: articles freely available online

- High visibility within the field

- Retaining the copyright to your article

Submit your next manuscript at springeropen.com 